\title{
Survival of rabbit eggs preserved in plastic straws in liquid nitrogen
}

\author{
Y. Tsunoda and T. Sugie \\ National Institute of Animal Industry, Chiba-shi, 280 Japan
}

Since the first successful report on the deep-freeze preservation of mouse embryos by Whittingham (1971), the development of frozen embryos after transplantation has been reported for the cow (Wilmut \& Rowson, 1973), rabbit (Whittingham \& Adams, 1974), rat (Whittingham, 1975), and sheep (Willadsen, Polge, Rowson \& Moor, 1976). For the rabbit, Bank \& Maurer (1974) found that $7-15 \%$ of 8 -cell eggs or morulae transplanted after freezing and thawing developed into fetuses, and Whittingham \& Adams (1974) also obtained a 17\% development of frozen 8-cell eggs to term. These results are considerably poorer than those obtained for the mouse (Whittingham, 1974).

Glass or plastic test tubes have been used for the preservation of frozen eggs in all studies except that of Utsumi \& Yuhara (1975) who used a plastic straw for freezing rat eggs. Plastic straws have been extensively used in many countries, including Japan, for the long-term preservation of semen in liquid nitrogen, and we therefore examined the survival of frozen-thawed rabbit eggs preserved in a plastic straw in liquid nitrogen.

Two-cell, 8-16-cell and late morulae were recovered in the medium of Brackett \& Williams (1968) at 24, 45 and $65 \mathrm{~h}$ post coitum from mature New Zealand White rabbits induced to superovulate with FSH and LH or HCG as described by Kennelly \& Foote (1965). The eggs were washed in two changes of medium and then moved to $0.1 \mathrm{ml}$ phosphate-buffered saline (PBS) (Whittingham, 1971) contained in a 1-ml capacity plastic straw $(4 \times 125 \mathrm{~mm}$ :Fujihira Co., Japan);0.05 $\mathrm{ml} 2.5 \mathrm{M}$-dimethylsulphoxide (DMSO) was added three times at 0 or $37^{\circ} \mathrm{C}$ at intervals of $10 \mathrm{~min}$ to give a final concentration of 1.5 M-DMSO. All samples were equilibrated for $15 \mathrm{~min}$ at each temperature after the final addition of DMSO. In one experiment, the plastic straws were transferred to room temperature after adding the DMSO at $37^{\circ} \mathrm{C}$ and then cooled to $-5^{\circ} \mathrm{C}$ at $1^{\circ} \mathrm{C} / \mathrm{min}$. In another experiment, the straws were cooled from room temperature to $0^{\circ} \mathrm{C}$ at $1^{\circ} \mathrm{C} / \mathrm{min}$, and again cooled to $-5^{\circ} \mathrm{C}$ at the same rate after adding the DMSO at $0^{\circ} \mathrm{C}$. The samples were induced to freeze by placing a supercooled pipette into the medium. After $5 \mathrm{~min}$, the eggs were cooled to $-76^{\circ} \mathrm{C}$ at $1{ }^{\circ} \mathrm{C} / \mathrm{min}$ by adding solid $\mathrm{CO}_{2}$ to $99 \%$ ethanol and transferred to liquid nitrogen vapour at $-100^{\circ} \mathrm{C}$ for $5 \mathrm{~min}$ by suspending the samples about $13 \mathrm{~cm}$ above the surface of the liquid nitrogen. The samples were finally transferred to liquid nitrogen at $-196^{\circ} \mathrm{C}$ and preserved for 1-21 days.

The samples were warmed from $-80^{\circ} \mathrm{C}$ to $0^{\circ} \mathrm{C}$ at approximately $4^{\circ} \mathrm{C} / \mathrm{min}$ as described by Tsunoda, Parkening \& Chang (1976). Immediately upon thawing, the DMSO was diluted from the samples at 0 or $37^{\circ} \mathrm{C}$ in a stepwise manner by the addition of $0.2,0.2$ and $0.4 \mathrm{ml}$ PBS at 1 -min intervals. The eggs were washed with PBS, moved to the Brackett \& Williams' medium containing $50 \%$ fetal calf serum, and kept at $37^{\circ} \mathrm{C}$ for $1-3 \mathrm{~h}$ pending transfer to one oviduct of synchronous pseudopregnant recipients which had received an injection of 60 i.u. HCG to induce ovulation. The transfers were performed on Day 1 of pseudopregnancy for 2-cell eggs, Day 2 for 8-16-cell eggs and Day 3 for late morulae. The recipients were examined by laparotomy at Day 17 of pregnancy to determine the numbers and condition of the implantations and then allowed to go to term.

Table 1 shows that the proportion of eggs which appeared morphologically normal after thawing was higher when the DMSO was diluted from samples at $37^{\circ} \mathrm{C}$ than at $0^{\circ} \mathrm{C}$, irrespective of the temperature at which it was added. Table 1 also shows that the proportion of live young after transfer of frozen eggs was significantly higher when the DMSO was added at $37^{\circ} \mathrm{C}$ than at $0^{\circ} \mathrm{C}$ even when the DMSO was diluted at $37^{\circ} \mathrm{C}$. The results of the present study are in agreement with those of Whittingham (1974) for the mouse, who reported that rapid removal of the DMSO from eggs at $37^{\circ} \mathrm{C}$ was essential for good survival, except that their highest survival rate was obtained when the DMSO was 
Table 1. Development to term after transfer to recipients of rabbit eggs preserved in a plastic straw in liquid nitrogen

\begin{tabular}{|c|c|c|c|c|c|c|c|}
\hline & \multicolumn{6}{|c|}{ Frozen eggs } & \multirow[b]{2}{*}{$\begin{array}{l}\text { Unfrozen eggs } \\
\text { (8-16-cell) }\end{array}$} \\
\hline & \multicolumn{2}{|c|}{2 -cell } & \multicolumn{2}{|c|}{ 8-16-cell } & \multicolumn{2}{|c|}{$\begin{array}{c}\text { Late } \\
\text { morulae }\end{array}$} & \\
\hline \multicolumn{8}{|l|}{ Temp. of DMSO $\left({ }^{\circ} \mathrm{C}\right)$} \\
\hline Addition & 37 & 37 & 37 & $\mathbf{0}$ & 0 & 37 & - \\
\hline Dilution & 37 & 37 & 0 & 37 & $\mathbf{0}$ & 37 & - \\
\hline No. of eggs frozen & 50 & 97 & 41 & 69 & 41 & 38 & - \\
\hline No. of normal eggs after thawing $(\%)$ & $16(32)$ & $81(84)$ & $1(2)$ & $51(74)$ & $2(5)$ & $29(76)$ & - \\
\hline No. of eggs transferred & 24 & 38 & 25 & 36 & 41 & 14 & 27 \\
\hline No. of recipients & 3 & 5 & 3 & 5 & 3 & 2 & 4 \\
\hline No. pregnant & 1 & 4 & $\mathbf{0}$ & 2 & 1 & 2 & 4 \\
\hline No. of implantations* $(\%)$ & $4(17)$ & $15(39)$ & $\mathbf{0}$ & $5(14)$ & $1(2)$ & $9(64)$ & 一 \\
\hline No. of live fetuses $(\%)$ & $3(13)$ & $14(37)$ & 0 & $4(11)$ & $1(2)$ & $9(64)$ & - \\
\hline No. of live young $(\%)$ & $3(13)$ & $14(37)$ & 0 & $1(3)$ & 0 & $9(64)$ & $17(63)$ \\
\hline
\end{tabular}

* Including some resorptions.

added at $0^{\circ} \mathrm{C}$ and diluted at $37^{\circ} \mathrm{C}$. Our results are also in accord with the observations of Whittingham \& Adams (1974) on the rabbit. They found that equilibration and dilution of the DMSO at $35^{\circ} \mathrm{C}$ was superior to any other temperature combination, although the details of the experiment were not available. Maurer \& Haseman (1976) found that the DMSO concentration and equilibration time were the critical factors for the freezing of rabbit morulae, and obtained live fetuses from $5-26 \%$ of the frozen and thawed morulae-a significantly lower proportion than that obtained with unfrozen eggs. In our study, the best development to living young (64\%) occurred after transfer of frozen late morulae, but 3 live young were born after transfer of 2-cell eggs treated in the same way. Under optimal conditions (8-16-cell and late morula stages and addition and dilution of DMSO at $37^{\circ} \mathrm{C}$ ) the pregnancy rate and proportion of eggs developing to term was not different from the results obtained with unfrozen eggs: $86 \%(6 / 7)$ versus $100 \%(4 / 4)$ of recipients pregnant and $44 \%$ $(23 / 52)$ versus $63 \%(17 / 27)$ of eggs developing to term.

The precise effect of the type of container on the survival of frozen rabbit eggs is still unknown, and the relationship between the stage and viability after freezing and thawing should be further studied.

Sincere thanks are due to T. Soma for assistance.

\section{References}

BANK, H. \& Maurer, R.R. (1974) Survival of frozen rabbit embryos. Expl Cell Res. 89, 188-196.

BracketT, B.G. \& Williams, W.L. (1968) In vitro fertilization of rabbit ova.J. exp. Zool. 160, 271-282.

KenNeldy, J.J. \& Foote, R.H. (1965) Superovulatory response of pre- and post-pubertal rabbits to commercially available gonadotrophins. J. Reprod. Fert. 9, 177-188.

MAURER, R.R. \& HASeman, J.K. (1976) Freezing morula stage rabbit embryos. Biol. Reprod. 14, 256-263.

Tsunoda, Y., Parkening, T.A. \& Chang, M.C. (1976) In vitro fertilization of mouse and hamster eggs after freezing and thawing. Experientia 32, 223-224.

Utsumi, K. \& Yuhara, M. (1975) Survival of rat eggs after freezing and thawing. Jap. J. Fert. Steril. 20, 102, Abstr.

WhIтTINGHAM, D.G. (1971) Survival of mouse embryos after freezing and thawing. Nature, Lond. 233, 125-126.

WhittinghaM, D.G. (1974) The viability of frozenthawed mouse blastocysts. J. Reprod. Fert. 37, 159-162.

Whittingham, D.G. (1975) Survival of rat embryos after freezing and thawing. J. Reprod. Fert. 43, 575-578.

Whittingham, D.G. \& Adams, C.E. (1974) Low temperature preservation of rabbit embryos. Cryobiology 11, 560-561, Abstr.

Willadsen, S.M., Polge, C., Rowson, L.E.A. \& Moor, R.M. (1976) Deep freezing of sheep embryos. J. Reprod. Fert. 46, 151-154.

Wilmut, I. \& Rowson, L.E.A. (1973) Experiments on the low temperature preservation of cow embryos. Vet. Rec. 92, 686-690. 